\title{
Administrative penalties for extortion of trees and bushes without permit - new law regulation
}

\section{Usuwanie drzew i krzewów bez zezwolenia - nowa regulacja prawna}

\author{
http://dx.doi.org/10.12775/PYEL.2015.003
}

\begin{abstract}
Amendment of the Act on the protection of nature, introduced by the Act of 25 June 2015 on amending the Act on Commune Self-government and other acts has significantly modified a model of an administrative fine which constitutes an administrative sanction for actions breaching of rules of green areas and afforestation protection. This change refers to objective and subjective aspects of torts, as well as a method of imposing financial sanctions. The introduced changes have significantly mitigated purely objective character of an administrative responsibility, providing a guarantee for, at least, minimal standards of imposing sanctions on individuals by the state.
\end{abstract}

" Doctor of Laws Environmental Law Protection Department, Faculty of Law and Administration of Nicolaus Copernicus University in Toruń, Poland. 
Keywords: Administrative sanctions; administrative fines; protection of trees or bushes; extortion of trees.

\section{Streszczenie}

Nowelizacja ustawy prawo ochrony przyrody, dokonana ustawą z dnia 25 czerwca 2015 r. o zmianie ustawy o samorządzie gminnym oraz niektórych innych ustaw ${ }^{1}$, w istotny sposób zmodyfikowała dotychczasowy model administracyjnej kary pieniężnej stanowiącej sankcję administracyjną za działania sprzeczne z przepisami o ochronie terenów zieleni i zadrzewień. Zmiana ta dotyczy zarówno znamion podmiotowych i przedmiotowych samych deliktów administracyjnych, jak i mechanizmu wymierzania sankcji pieniężnych. Wprowadzone zmiany w istotny sposób łagodzą ściśle obiektywny charakter odpowiedzialności administracyjnej, gwarantując tym samym zachowanie przynajmniej minimalnych standardów stosowania przez państwo sankcji wobec jednostki.

Słowa kluczowe: Sankcje administracyjne; kary administracyjne; ochrona drzew i krzewów; usuwanie drzew.

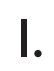

By the judgement of 1 July $2014^{2}$ the Constitutional Tribunal ruled that article 88 item 1 point 2, and article 89 item 1 of the Act of 16 April 2004 on the protection of nature ${ }^{3}$ are inconsistent with article 64 item 1 and 3 in connection with article 31 item 3 of The Constitution of the Republic of Poland ${ }^{4}$, because of their stipulation stating an imposition, by a competent local government body, of an administrative fine of strictly defined amount on an owner of a property where a tree or bush is located for extraction without a required permit or destruction of a tree or bush, regardless of its

\footnotetext{
1 Journal of Laws of 2015, item 1045.

2 Judgement of The Constitutional Tribunal of 1 July 2014, SK 6/12, OTK-A, p. 7, item 68.

3 Journal of Laws of 2013, item 627 with further amendments, hereinafter referred to as the Act on the protection, abbreviated to PNA.

4 Act of 2 April 1997 Constitution of the Republic of Poland, Journal of Laws of 1997, No 78, item 483 with further amendments, hereinafter referred to as The Polish Constitution.
} 
circumstances. In connection with the above mentioned judgement, the Act of 25 June 2015 on amending the Act on Commune Self-government and other acts ${ }^{5}$ was passed. The new act was used to amend the Act on the protection of nature in relations to, amongst others, rules of imposing an administrative fine as a sanction measure for violation of rules of trees and bushes protection. On their entering into force on 28 August 2015, the amended regulations have caused a profound change in the usage of financial fines in trees and bushes protection.

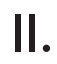

In the previously binding case $\mathrm{law}^{6}$ administrative fines were imposed for committing torts including:

1) destruction of green areas or trees or bushes caused by improper realization of earthmoving, or misuse of machinery or technical tools and usage of chemical substances in a way which is harmful to plant life,

2) extortion of trees or bushes without required permit,

3) destruction of trees, bushes or green areas caused by improper maintenance activities.

In spite of lack of unambiguous statutory definition of the scope of subjective responsibility for extortion of trees and bushes without a required permit in doctrine of law or in jurisdiction an opinion has been formed that a tort in a form of trees and bushes removal conducted without a required permit can be attributed only to an owner of a premises or an owner of utility devices as only these entities are obliged to obtain the permit ${ }^{7}$. In the same

Journal of Laws of 2015, item 1045.

In force till 28 August 2015.

7 K. Gruszecki, Ustawa o ochronie przyrody. Komentarz, Warszawa 2010, p. 401402; W. Radecki, Optaty i kary pieniężne w ochronie środowiska, in: Ustawa o ochronie i ksztattowaniu środowiska. Komentarz, ed. J. Sommer, vol. I, Wrocław 1993, p. 28; B. Rakoczy, Usuwanie drzew i krzerwów, Warszawa 2013, ebook, p. 111-115; Judgement of Voivodeship Administrative Court in Gdańsk of 24 October 2007, file reference no II SA/Gd 661/06, Lex No 384133, Judgement of Supreme Administrative Court in Warszawa of 10 April 2007, file reference no IV SA/Wa 90/07, Lex No 339447, Judgement of Supreme Administrative Court in Warszawa of 11 March 2009, file reference no II OSK 329/08, Lex No 529956, 


\section{Małgorzata Szalewska}

time jurisdiction stated that an administrative responsibility stipulated by article 88 of PNA could not be placed only on activities of a person being fined, they were also held responsible for such actions of a third party on which they agreed, gave their approval of or ordered ${ }^{8}$. A contrario if trees have been removed by a third party without consent or knowledge of a real estate owner, then the owner was not faced with any liabilities stipulated by article 88 item 1 point 2 of PNA. Moreover, the third party could not be faced with an administrative responsibility as according to law regulations they were not obliged to obtain the permit. In cases of other torts, including a destruction of green areas or trees or bushes caused by improper maintenance activities, improper realization of earthmoving, or misuse of machinery or technical tools and usage of chemical substances in a way which is harmful to plant life, a responsibility for the abovementioned actions was placed on entities conducting them ${ }^{9}$.

An administrative fine for extortion of trees and bushes without a permit, destruction of trees, bushes or green areas conducted under circumstances stipulated by article 88 of PNA, was obligatorily imposed in a form of an administrative decision by an executive body of a commune. The decision was of mandatory nature, which meant that an administrative body stating a fact of extortion of trees or bushes without a permit by an entity obliged to had obtained it, or stating a fact of destruction of trees, bushes or green areas was bound by law to impose an administrative fine ${ }^{10}$. In case of extortion of trees and bushes without a permit, a tort was determined by a lack of permission to do so, issued by an administrative body. Hence, an action was perceived as a tort only when a permit was required. Regardless of a fact of committing it as a reason for imposing an administrative fine, a fee for extortion of trees

Judgement of Supreme Administrative Court in Warszawa of 9 June 2009, file reference no IV SA/Wa 1957/08, Lex No 564013, Judgement of Supreme Administrative Court in Warszawa of 24 April 2012, II OSK 2406/10, CBOSA (Central Database of Administrative Courts Judgements), Judgement of Voivodeship Administrative Court in Gdańsk of 9 June 2013, II SA/Gd 121/13, CBOSA.

8 Judgement of Supreme Administrative Court in Warszawa of 10 December 2014, II OSK 2712/14, CBOSA, Judgement of Voivodeship Administrative Court in Gliwice of 24 October 2014, II SA/G1 1022/14 CBOSA, Judgement of Voivodeship Administrative Court in Gliwice of 31 October 2014, II SA/G1 1023/14, CBOSA.

9 Judgement of Voivodeship Administrative Court in Gliwice of 16 July 2014, II SA/G1 $168 / 14$, CBOSA.

10 Judgement of Voivodeship Administrative Court in Poznań of 26 August 2009, II SA/G1 168/14, CBOSA. 
and bushes was placed on a real estate owner or an owner of utility devices. As it has been noted by W. Radecki, an administrative fine for extortion of trees without a required permit was imposed regardless of whether a fee would have been charged in the process of applying for a permit, or not ${ }^{11}$.

The amount of administrative fines for extortion of trees and bushes without a permit, or destruction of trees, bushes or green areas was defined by the previously binding case law in a strict manner by multiplying a fee for legal extortion of trees and bushes, and in case of green areas by quota defining a fine for destruction of 1 square metre. Accepted normative construction constituted a ground for a model of sanctioning a breach of protection rules of green areas and afforestation based on implicitly defined financial sanctions. As M. Wincenciak has noticed, strictly defining the amount of fine brought its scope to an arithmetic calculation in which a size of law violation (e.g. acreage in case of green areas, measurement of a trunk in case of trees) was multiplied by charge rates stipulated by law regulations ${ }^{12}$. An administrative body imposing an administrative fine did not allow for any "decisional freedom", it could not shape its amount according to its own opinion, nor could it take into consideration special circumstances, like utmost necessity, misdemeanour nature of action or financial situation of the fined ${ }^{13}$.

\section{III.}

This model of sanctioning breach of protection rules of green areas and afforestation was undermined by the Constitutional Tribunal in its judgement

11 W. Radecki, Ustawa o ochronie przyrody. Komentarz, Warszawa 2008, p. 268.

12 M. Wincenciak, Sankcje w prawie administracyjnym i procedura ich wymierzania, Warszawa 2008, p. 120. In W. Radecki's opinion, accepted model of administrative financial penalty for extortion of trees and bushes without a permit validates theses that the penalty is imposed not awarded because it is determined by a few simple arithmetic calculations; W. Radecki, Odpowiedzialność karna, in: Instytucje prawa ochrony środowiska. Geneza, rozwój, perspektywy, ed. W Radecki, Warszawa 2010, p. 445.

13 Compare A. Kaźmierska-Patrzyczna, A. Rabiega-Przyłęcka, Sankcje administracyjne na przyktadzie administracyjnych kar pieniężnych za usuwanie bez zezwolenia lub niszczenie drzew i krzewórw, in: Sankcje administracyjne, eds. M. Stahl, R. Lewicka, M. Lewicki, Warszawa 2011, p. 447. 
of 1 July 2014. The Tribunal sustained its opinion ${ }^{14}$ that it was acceptable from constitutional point of view to impose financial fines for beaching of public law, aside from criminal law. Especially including administrative fines imposed in different spheres of administrative law in order to ensure the effectiveness of its norms and regulations by means of general and detailed preventive measures. The Tribunal underlined numerous assets of that model of sanctioning breach of legal bans or not complying with responsibilities laid in the public interest, indicating that, first of all, penalties of these kinds could be imposed on both, individual and collective entities. Secondly, they were easy to apply as the grounds of fining was, indeed, a breach of defined law regulation, without analysing a subjective behaviour of the committer. Thirdly, they were imposed by a public administration body in an administrative procedure under supervision of an administrative court, which is far less complicated and expensive for the budget than a criminal procedure. Fourthly, due to the abovementioned assets, the penalties were usually imposed immediately and inevitably. Admissibility of sanctioning breach of administrative law by a system of administrative sanctions, including administrative fines did not make Legislator free of maintaining, at least, minimal standards in that scope. The Tribunal underlined that Legislator's freedom boundaries were set by constitutional principles of a democratic lawful state, freedom and rights protection of individuals, as well as principles of proportionality, equality and justice. Imposing administrative penalties could not be based on an idea of strictly objective responsibility, which was set apart from circumstances of a given case, including a guilt of a committer. Minimal standard in this aspect was established by the judgement of the Constitutional Tribunal of 1 March $1994^{15}$, which stipulated that an entity which did not comply

14 Judgement of the Constitutional Tribunal of 1 March 1994, U 7/93, OTK of 1994, section I, item 5, Judgement of the Constitutional Tribunal of 26 April 1995, K 11/94, OTK of 1995, section I, item 12, Judgement of the Constitutional Tribunal of 26 September 1995, U 4/95, OTK ZU of 1995, No 1, item 4, Judgement of the Constitutional Tribunal of 27 April 1999, P 7/98, OTK ZU of 1999, No 4, item 72, Judgement of the Constitutional Tribunal of 23 April 2002, file reference no K 2/01, OTK ZU of 2002, No 3A, item 27, Judgement of the Constitutional Tribunal of 14 June 2004, SK 21/03, OTK ZU of 2004, No 6A, item 56, Judgement of the Constitutional Tribunal of 31 March 2008, file reference no SK 75/06, OTK ZU of 2008, No 2A, item 30.

15 Judgement of the Constitutional Tribunal of 1 March 1994, U 7/93, OTK of 199, section I, item 5 . 
with an administrative responsibility must be granted a possibility to be relieved of this responsibility by indicating that not complying with the responsibility was a result of circumstances for which they could not be held responsible (force majeure, utmost necessity, third party's action). Conditions of imposing fines and their amounts should have been shaped by Legislator in a manner that corresponded with the principle of adequate interference of the state in constitutionally protected sphere of individuals (article 2 of the Polish Constitution). Their severity should have been adequate to a degree of breach of rights protected by means of the penalties, and in case of penalties for extraction of trees and bushes without a permit, and destruction of trees, bushes or green areas - to a degree of destruction of natural environment. In the opinion of the Constitutional Tribunal, Legislator establishing sanctions should have taken into consideration financial situation of the fined entity, which constituted a significant factor of severity of a penalty; for a person with low income, a high rate of a fine could cause a degradation of their financial status. Taking these circumstances into consideration should have been left for assessment of a body making a decision to impose a fine, and a court of law supervising that decision, which should have considered all circumstances of a given case. The Tribunal highlighted full acceptance of nature protection (afforestation) mechanism, including: an obligation to obtain a competent body's permit for extraction of trees and bushes, which, as stipulated in bills of law, in certain situations was connected with imposing a charge (in reasonable amount), and a penalty for not complying with that obligation. The Tribunal did not undermine the accepted concept of an administrative penalty as a sanction for unlawful act which violated an administrative responsibility, on condition of taking all individual circumstances of a given case into legal consideration in a process of imposing a penalty.

In spite of stating discrepancies of article 88 item 1 point 2 and article 89 item 1 of PNA (in its wording being in force till 28 August 2015), the Constitutional Tribunal adjourned loss of binding force of the undermined regulations for a period of 18 months from the date of publication of its judgement in Journal of Laws, that is till 14 January 2016. At the same time, an opinion emerged in administrative jurisdiction that, in individual cases, in spite of the Tribunal adjournment, stipulated in its judgement of 1 July 2014, of loss of binding force of article 88 item 1 point 2 and article 89 item 1 of PNA, taking the aim for adjournment into consideration, a fact of stating discrepancies of the abovementioned 
regulations with the Polish Constitution, as well as functions and statutory objectives of administrative courts, and their juridical autonomy allowed for denial of application of the regulations by courts of law. As a consequence, cassation appeal for decisions issued on the grounds of article 88 item 1 point 2 and article 89 of PNA should be considered in defined cases, regardless of legal basis listed in the decision (article 190 item 1 and 4 of the Polish Constitution) $)^{16}$.

\section{IV.}

In that state, the Act of 25 June 2015 on amending the Act on Commune Self-government and other acts was passed. On the grounds to its article 29, significant changes have been made in the Act on the protection of nature, in the scope of permit for extortion of trees and bushes, and sanction of unlawful acts in that area.

In the prevailing case law, a significant modification of subjective and objective scope of responsibility for breach of trees and bushes protection rules has been made. Moreover, Legislator has taken into consideration opinions of the Constitutional Tribunal concerning minimal standards of applying administrative financial penalties.

According to article 88 of PNA, in its wording being in force till 28 August 2015, an administrative financial penalty can be imposed for committing administrative torts, including:

1) extortion of a tree or a bush without a required permit,

2) extortion of a tree or a bush without consent of a real estate owner,

3) destruction of a tree or a bush,

4) damage to a tree caused by activity done in a tree crown area.

As to the first of the abovementioned torts, Legislator has only made a slight linguistic change of replacing word "extorting" with "having extorted" 17 . Similarly to the previously binding case law, a subject matter

16 Judgements of Supreme Administrative Court of 4 December 2014, II OSK 2696/14 and II OSK 2697/4, CBOSA.

17 According to opinion of the Constitutional Tribunal „Any precision is given to article 88 item 1 point 2 of PNA by using word "extorting" which indicates repetitive action and plural forms of nouns "tree" and "bush" ("trees or bushes")". 
of this issue is a violation of obligation to obtain a permit to extort a tree or a bush. An administrative responsibility applies only to cases of previously stated existence of obligation to obtain such a permit. According to article 83 item 1 of PNA, extortion of a tree or a bush from real estate territory shall be conducted after having obtained a permit issued on the request of: 1) real estate owner, 2) owner of machinery stipulated by article 49 item 1 of the Act of 23 April 1964 - the Civil Code ${ }^{18}$ - if a tree or a bush endangers functioning of these devices. At the same time, Legislator, by article $83 \mathrm{f}$ item 1 of PNA, defines a 'numerus clausus' catalogue of cases when obligation to obtain a permit has lost its binding force. Hence, extortion of trees and bushes is done after obtaining a competent body permit, excluding cases stipulated by article $83 \mathrm{f}$ item 1 of PNA. An important change concerning obligation to obtain a permit is inclusion into the catalogue stipulated by article $83 \mathrm{f}$ item 1 of PNA, of trees and bushes which constitute windsnaps and windthrows which are removed by: a) firefighter units, the Polish army units, owners of devices stipulated by article 49 item 1 of the Civil Code, roads administrators, railway administrators, communal and county cleansing services or other entities acting in this scope of actions on a commune or county order, b) other entities or persons, after a competent body issuing a permit has inspected a location and proved that trees and bushes are indeed windsnaps or windthrows. It means that in cases of entities listed in point $b$, a permit refers only to cases when having inspected a location, a competent body confirms that trees and bushes are indeed windsnaps or windthrows. In case of extorting a tree or a bush which is a windsnap or a windthrow with a breach of inspection rule, the action is considered as an administrative tort and can be punished with a financial penalty. The second of the abovementioned torts - extortion of a tree or a bush without consent of a real estate owner, constitutes novum in the area of an administrative responsibility for breaching of trees and bushes protection rules. The applied solution is a response to a legal void which has been detected byjudgements of courts which have denied placing an administrative responsibility on persons, other than real estate owner, who extorted a tree or a bush. Jurisdiction and doctrine of nature protection law has underlined that an entity not obliged to obtain a permit cannot be held responsible for extortion of trees and bushes. Currently, it should be assumed that in case

18 Journal of Laws 2014, item 121 with further amendments. 
of extortion of a tree or a bush by a third party (not a real estate owner) done with a consent of that owner, the owner shall be held responsible for extortion of trees and bushes without a permit. If a third party extorts a tree without a consent of a real estate owner, then the third party shall be held responsible and punished with a fine. The applied solution aims at limitation of cases of avoiding a responsibility by appointing persons other than factual real estate owners as culprits.

Another tort stipulated by article 88 item 1 of PNA, is destruction of a tree or a bush. It should be indicated that in the previously binding case law acts punished with an administrative penalty included: 1) improper realization of earthmoving, 2) misuse of mechanical gear or technical devices, 3) usage of chemical substances in a way which is harmful to plant life, 4) improper maintenance activities. It means that Legislator has waived penalties for destruction of green areas, and has relinquished to name the cause of trees and bushes destruction ${ }^{19}$. In the previously binding case law, administrative courts indicated that Legislator did not connect administrative sanctions with all cases of trees, bushes or green areas destruction, but only with those cases when a destruction was caused by e.g. improper realization of earthmoving or improper maintenance activities ${ }^{20}$. In the prevailing case law circumstances of destruction of a tree or a bush shall not influence a fact of committing an administrative tort.

19 Loss of binding force of article 82 of PNA, according to which 1. Earthmoving and other works with a usage of mechanical gear and technical devices done to root areas of trees and bushes in green areas and afforestation terrain shall be done in the least invasive manner. 1a. works to a tree crown area in green areas and afforestation terrain include only: 1) removing of branches which are dead, broken, or colliding with buildings or technical devices, 2) shaping of a tree crown which is no older than 10 years, 3) maintaining of a shaped tree. 2. Usage of chemical substances on public roads, streets and squares shall be conducted in the least invasive to green areas and afforestation terrain manner. 3. A minister competent for environmental issues indicates, by means of regulation, types of chemical substances which can be used in places stipulated in point 2 , as well as conditions of their usage taking into consideration the need to ensure road traffic safety, protection of landscape and biological variety, as well as appropriate road maintenance and safety usage of roads. Compare A. Jaworowicz-Rudolf, Zarys prawnej reglamentacji usuwania drzew i krzewów de lege lata oraz w świetle propozycji zmian ustawowych, in: Dobre prawo - sprawne rzadzenie, ed. B. Jaworska-Dębska, Łódź 2015, p. 409.

20 Judgement of Voivodeship Administrative Court in Gliwice of 2 October 2014, II SA/G1 977/14, CBOSA. 
According to article 88 item 1 point 4 of PNA, financial penalties can be also imposed for a damage to a tree caused by activity done in a tree crown area. In the previously binding case law an act of destruction of trees, bushes or green areas caused by improper maintenance activities was punished with an administrative penalty. Sanctioning damage caused to a tree by activity done in a tree crown area, Legislator indicated loss of binding force of article 82 item 1a of PNA, according to which activity done in a tree crown area of a tree located on green areas or afforestation terrain included only: 1) removing of branches which are dead, broken, or colliding with buildings or technical devices, 2) shaping of a tree crown which is no older than 10 years, 3) maintaining of a shaped tree. The previous article 82 of PNA has been replaced by an elaborated law regulation stipulated by article 87a of PNA. According to this regulation all earthmoving and other works, including hand works, works with mechanical gear and technical devices, done to a tree crown area shall be conducted in the least invasive manner. The works shall not lead to removal of branches exceeding 30\% of a tree crown which has developed throughout its lifespan, unless they aim at: 1) removing of branches which are dead, broken, or colliding with buildings or technical devices, 2) maintaining of a shaped tree crown, 3) conducting specialised action to restore statics of a tree. Act stipulated by point 3 is conducted basing on documentation, including photographic documentation, which indicates a necessity of that act. According to article $87 \mathrm{a}$ items 4 and 5 of PNA, removal of branches exceeding 30\% of a tree crown which has developed throughout its lifespan, with the aim other than stipulated by article 87 item 2 of PNA constitutes a damage. However, removal of branches exceeding $50 \%$ of a tree crown which has developed throughout its lifespan, with the aim other than stipulated by article 87 item 2 of PNA constitutes a destruction. Legislator has empowered a minister competent for environmental issues to indicated, by means of a regulation, a method of conducting works stipulated by article 87a item 1 of PNA, which shall be conducted in the least invasive and damaging to a tree manner. However, a regulation is of facultative character.

The change of the scope of objective responsibility for breaching of trees and bushes protection rules has been connected with a change of its subjective scope. By critical assessment of the previous case law concerning lack of indication of required objective elements of torts, Legislator has settled expressis verbis this issue by article 88 item 2 of PNA, according to which, a penalty stipulated by article 88 item 1 of PNA shall be imposed 
on a real estate owner, or owner of machinery stipulated by article 49 item 1 of the Civil Code, or other entity acting without a consent of a real estate owner.

From the point of view of the content of the Constitutional Tribunal judgement of 1 July 2014, the change of imposing administrative financial penalties for torts stipulated by article 88 item 1 of PNA, is particularly important. According to article 89 item 2 of PNA, an administrative fine, which is stipulated by article 88 item 1 points $1-3$, amounts to a double fee for extortion of trees and bushes, stipulated by article 84 item 1 of PNA. It means that Legislator has kept a model of indicating amount of a fine as multiple fee, stipulated by article 89 of PNA in its wording in force till 28 August 2015. Legislator has also lessen severity of a penalty by changing a fee rate from triple to double. An administrative financial penalty for damage to a tree caused by activity done in a tree crown area shall amount to a fee for extortion of a tree, stipulated by article 84 item 1 of PNA, multiplied by 0,6 . In case of extortion of a tree or a bush which is dead or likely to become dead, or a windsnap, or a windthrow, the amount of an administrative fine shall be lowered by $50 \%$.

New solution introduced into the Act on the protection of nature, is a possibility to avoid an administrative responsibility for torts stipulated by article 88 item 1 of PNA, by indicating that extortion or destruction of a tree or a bush, or a damage to a tree resulted from circumstances occurring in a state of utmost necessity. According to article 89 item 7 of PNA, in such case an administrative fine is not imposed. Doctrine of the criminal law defines utmost necessity as actions taken with the aim of evasion of direct danger which endangers law protected goods by sacrificing other goods which are also law protected ${ }^{21}$. Hence, a state of utmost necessity is a classic collision of goods. Hence, law should precisely stipulate conditions under which endangered goods can be saved with loss of other goods, including: subsidiarity, proportion of goods and limitation of a right to make use of a state of utmost necessity ${ }^{22}$. Danger is understood as a configuration of phenomena in which a real danger to a protected good occurs, that is a probability of destroying or damaging that good (life, health, ownership,

21 A. Marek, Kodeks karny. Komentarz, Warszawa 2010, electronic version/Lex.

22 Ibidem. More on the issue of a state of utmost necessity, J. Lachowski, Stan wyższej konieczności w polskim prawie karnym, Warszawa 2005. 
etc.). Danger must be of a direct nature. Doctrine of $\mathrm{law}^{23}$ and jurisdiction ${ }^{24}$ assume that danger occurs when there is a high level of probability of destruction or damage of goods, and when any delay of rescue action may only enlarge the scope of danger or lead to immediate damage. Acting in a state of utmost necessity justifies unlawfulness of action. Relating the above to the issue of extortion of trees and bushes, their destruction or damage, it should be indicated that a state of utmost necessity shall occur only when taken actions lead to evasion of direct danger which endangers law protected goods (life, health, ownership), and when there is no other possibility to evade that danger.

An administrative fine for torts stipulated by article 88 item 1 of PNA is imposed by a local governing body in a form of an administrative decision. Fine is obligatory. A body, having any knowledge of a state of fact required as an element of an act stipulated by article 88 item 1 of PNA, is obliged to impose a penalty on a committer of that act. According to article $88 \mathrm{item}$ 3 of PNA, a fine shall be paid within 14 days from the day when a decision is made final. It means that a body issuing a decision to impose a fine cannot set the date of payment as it is stipulated by law regulations.

Similarly to the previous case law, payment date of a fine imposed on the grounds of article 1 item 3 is adjourned, if a degree of a tree or a bush destruction does not exclude its liveliness. Legislator has prolonged a period of adjournment from 3 to 5 years. Adjournment of payment of a fine for destruction of a tree crown relates to $70 \%$ of that fine. Having stated liveliness of a tree or a bush after the period of adjournment, or lack of liveliness of a tree or a bush caused by reasons not connected with actions of the fined entity, a fine is remitted. If stating that a tree or a bush has died before a period of 5 years from the day when an adjournment decision is made final, a fine is paid immediately, unless a tree or a bush lost its liveliness because of reasons not connected with actions of the fined entity.

Act on the protection of nature introduces two forms of allowances, in the context of financial penalties imposed on an entity for committing administrative torts stipulated by article 88 item 1of PNA, which are instalment payment and remission of the amount of duty. Instalment payment is decided on by an administrative body on request of the fined, which is submitted within 14 days from the day when a decision is made

23 J. Lachowski, op. cit., p. 79,

24 Judgement of Supreme Court of 30 May 1973, III KR 6/73, Lex No 21565. 
final, or from the day of adjournment of payment the amount of duty. Decision on instalment payment is made discretionarily. Legislator does not indicate any circumstances which should be taken into consideration by an administrative body issuing a decision. It means that a judgement should be based on the general rules of administrative proceedings, especially on principle of the public interest and rightful interest of an entity. Penalty can be paid on instalments for a period no longer than 5 years. The second form of allowance constitutes a new solution resulting from judgement of the Constitutional Tribunal of 1 July 2014. One of the reproaches stipulated by this judgement is a complete lack of consideration, in law regulations concerning administrative penalties in environmental protection, of financial capability of the fined entity. Hence, legislator has introduces into the Act on the protection of nature article 89 item 11, according to which a body can remit $50 \%$ of a fine stipulated by article 89 item 1 or 2 of PNA which is imposed on natural persons who extracted, destructed or damaged a tree or a bush for reasons not connected with their business activity, if they are unable to pay all amount of a fine, if their monthly income counted on each household member does not exceed 50\% of minimal wages in a current year. Similarly to instalment payment, decision on remission of $50 \%$ of a fine is made discretionarily, which means that even if an entity fulfils all the abovementioned requirements, an administrative body can (but does not have to) remit a part of the amount of duty. It should be highlighted that a decision can refer only to $50 \%$ of that amount. A body assessing factual and law situation, and deciding on remission cannot remit less than $50 \%$ of the amount, but it can deny any remission.

Penalty for committing torts stipulated by article 88 item 1 of PNA, as well as prosecution of these acts are subject to limitation of legal proceedings within dates stipulated by article 98 items 9 and 10 of PNA. Any liabilities resulting from an administrative fine are subject to limitation of legal proceedings within 5 years from the last day of a year when payment date expires ${ }^{25}$. Prosecution of an act is subject to limitation of legal proceedings within 5 years from the last day of a year of extortion or destruction of a tree

25 According to article 88 item 3 of PNA, payment of the imposed fine is made within 14 days since the day when a decision is made final, unless the payment date, according to article 88 item 4 of PNA, is subject to adjournment. Then payment date is stipulated by adjournment. 
or a bush, or a damage of a tree. After expiration date new administrative proceedings is not instituted, and the previous one is remitted.

\section{V.}

Amendment of the Act on the protection of nature, introduced by the Act of 25 June 2015 on amending the Act on Commune Self-government and other acts ${ }^{26}$ has significantly modified a model of an administrative fine which constitutes an administrative sanction for actions breaching of rules of green areas and afforestation protection. This change refers to objective and subjective aspects of torts, as well as a method of imposing financial sanctions. Legislator, by taking into consideration the opinion of the Constitutional Tribunal, has introduced into the Act on the protection of nature an important element of mitigation of the scope of an administrative penalty, that is a mechanism of taking into consideration a financial situation of the fined by a possibility to remit a fine, and a state of utmost necessity as a requirement for adjournment of prosecution of an act. The introduced changes have significantly mitigated purely objective character of an administrative responsibility, providing a guarantee for, at least, minimal standards of imposing sanctions on individuals by the state.

\section{Bibliography}

Gruszecki K., Ustawa o ochronie przyrody. Komentarz, Warszawa 2010.

Jaworowicz-Rudolf A., Zarys prawnej reglamentacji usuwania drzew i krzewów de lege lata oraz w świetle propozycji zmian ustawowych, in: Dobre prawo - sprawne rzązenie, ed. B. Jaworska-Dębska, Łódź 2015.

Kaźmierska-Patrzyczna A., Rabiega-Przyłęcka A., Sankcje administracyjne na przyktadzie administracyjnych kar pieniężnych za usuwanie bez zezwolenia lub niszczenie drzew i krzerwórw, in: Sankcje administracyjne, eds. M. Stahl, R. Lewicka, M. Lewicki, Warszawa 2011.

Lachowski J., Stan wyższej konieczności w polskim prawie karnym, Warszawa 2005. Marek A., Kodeks karny. Komentarz, Warszawa 2010.

26 Journal of Laws of 2015, item 1045. 


\section{Małgorzata Szalewska}

Radecki W., Ustawa o ochronie przyrody. Komentarz, Warszawa 2008.

Radecki W., Optaty i kary pieniężne w ochronie środowiska, in: Ustawa o ochronie $i$ ksztattowaniu środowiska. Komentarz, ed. J. Sommer, vol. I, Wrocław 1993.

Radecki W., Odpowiedzialność karna, in: Instytucje prawa ochrony środowiska. Geneza, rozwój, perspektywy, ed. W Radecki, Warszawa 2010.

Rakoczy B., Usuwanie drzew i krzewów, Warszawa 2013.

Wincenciak M., Sankcje w prawie administracyjnym i procedura ich wymierzania, Warszawa 2008.

\section{Email}

szalewska@wp.pl 